\title{
Studi Mengenai Pengaruh Gradasi Agregat Kasar terhadap Kebutuhan Air untuk Mencapai Suatu Kelecakan Campuran Beton pada Cara SNI
}

\author{
BAYU NUGRAHA, PRIYANTO SAELAN \\ Jurusan Teknik Sipil Institut Teknologi Nasional Bandung \\ Email: bayu.und@gmail.com
}

\begin{abstract}
ABSTRAK
Kebutuhan air untuk mencapai suatu rentang kelecakan campuran beton yang direncanakan pada cara SNI hanya bergantung pada ukuran maksimun agregat kasar dan jenis agregat yang digunakan. Pada cara SNI ini banyaknya ragam gradasi agregat kasar yang digunakan selama ukuran maksimumnya tidak berubah, maka jumlah air yang dibutuhkan tetap sama. Kejelasan tentang jenis gradasi agregat kasar yang terdapat pada perkiraan jumlah air dalam campuran beton sangat perlu untuk memperhitungkan kebutuhan air campuran beton menjadi lebih tepat. Penelitian ini dilakukan untuk mengetahui pengaruh gradasi agregat kasar terhadap kebutuhan air campuran beton pada cara SNI. Kebutuhan air campuran beton berbanding lurus dengan persentase jumlah air tiap ukuran agregat kasar yang digunakan. Hasil penelitian menunjukan bahwa jumlah air yang dibutuhkan sesuai dengan perhitungan jumlah air yang dihitung. Jumlah air yang dibutuhkan dapat dirumuskan sebagai jumlah dari persen ukuran agregat kasar dikali jumlah air dari tiap ukuran agregat kasar tersebut.
\end{abstract}

Kata kunci: cara SNI, gradasi agregat kasar, kebutuhan air

\begin{abstract}
Amount of waters that need to reach a slump range of mix concrete that planned on SNI only depending on maximum amount of coarse aggregate and the kind of aggregate. Depending of SNI, variety of graded coarse aggregate as long as the maximum amount does not change or stable does not change the amount of water needed. Clarity of the kind of coarse aggregate graded on water amount estimate to calculate a water on mix concrete to be accurate. The study was done to overcome the effect coarse aggregate graded to amount of water needed on SNI. The water needed mix concrete directly proportional with percentage of water every size of coarse aggregate used. The result shown that amount of water needed equivalent with calculation of water that calculated. Amount of water needed can be formulated as a total of percentage size of coarse aggregate multiplied by amount of water of every size of coarse aggregate.
\end{abstract}

Keywords: SNI method, coarse aggregate graded, water needed 


\section{PENDAHULUAN}

Kebutuhan air untuk mencapai suatu kelecakan campuran beton yang direncanakan pada perancangan campuran beton cara SNI bergantung pada ukuran maksimun agregat kasar dan jenis agregat yang digunakan. Selama ukuran maksimum agregat tidak berubah, maka jumlah air yang diperlukan untuk mencapai suatu rentang kelecakan akan sama untuk berbagai faktor air-semen yang digunakan. Dengan perkataan lain kebutuhan air tidak dipengaruhi oleh kuat tekan beton, tetapi hanya ditentukan oleh tingkat kelecakan yang direncanakan sesuai dengan ukuran maksimun agregat yang digunakan. Ukuran maksimum agregat yang terdapat pada perkiraan jumlah air yang dibutuhkan untuk mencapai kelecakan pada cara SNI, tidak menunjukan gradasi agregat kasar secara jelas. Dengan demikian kejelasan tentang jenis gradasi agregat kasar yang terdapat pada perkiraan jumlah air dalam campuran beton untuk mencapai suatu kelacakan pada cara SNI masih belum secara nyata ditampakkan. Untuk itu perlu diteliti lebih lanjut sehingga dapat diketahui pengaruh gradasi agregat kasar terhadap kebutuhan air tersebut.

\section{TINJAUAN PUSTAKA}

\subsection{Kelecakan Campuran Beton}

Kelecakan campuran beton adalah mudah tidaknya campuran beton dikerjakan. Proses pengerjaan beton merupakan serangkaian pelaksanaan pengadukan, penuangan,dan pemadatan. Kelacakan campuran beton pada umumnya diukur dengan melakukan percobaan uji slump. Tingkat kelecakan campuran beton ditunjukan pada Tabel 1.

Tabel 1. Tingkat Kelecakan Campuran Beton

\begin{tabular}{cccc}
\hline \multirow{2}{*}{ Tingkat Kelecakan } & \multirow{2}{*}{ Kekentalan Adukan Beton } & \multicolumn{2}{c}{ Nilai Slump [mm] } \\
\cline { 3 - 4 } & & SNI & Road Note no. 4 \\
\hline Sangat rendah & Sangat kental & $0-10$ & $0-25$ \\
Rendah & Kental & $10-30$ & $25-50$ \\
Sedang & Sedang & $30-60$ & $50-100$ \\
Tinggi & Encer & $60-180$ & $100-175$ \\
\hline
\end{tabular}

Faktor-faktor yang mempengaruhi kelecakan campuran beton segar adalah:

1. Kadar Air

Semakin banyak penggunaan air maka kelecakan campuran beton akan semakin tinggi, sehingga campuran beton akan lebih encer dan mudah dalam proses pekerjaan.

2. Faktor Air-Semen

Faktor air-semen yang tinggi menunjukan bahwa jumlah air lebih banyak dari pada jumlah semen. Semakin tinggi faktor air-semen maka semakin mudah campuran beton dikerjakan untuk kadar semen yang sama. Hubungan faktor air-semen dengan kelecakan campuran beton dapat ditunjukan berdasarkan penelitian. Jika ukuran agregat maksimum yang digunakan kurang lebih dari 2,0 cm, maka jumah air $(w)$ harus dikoreksi dengan faktor koreksi ditunjukan pada Tabel $\mathbf{2}$.

Tabel 2. Faktor Koreksi Kadar Air

\begin{tabular}{cccccccc}
\hline Ukuran Maksimum Agregat [mm] & 5 & 8 & 12,5 & 20 & 31,5 & 50 & 80 \\
Koreksi Jumlah Air [\%] & +15 & +9 & +4 & 0 & -4 & -8 & -12 \\
\hline
\end{tabular}

3. Besar butir Agregat Maksimum

Semakin besar agregat maksimum maka semakin sedikit kebutuhan air yang diperlukan. Jika agregat maksimum lebih kecil, maka kebutuhan air untuk membasahi total luas 
permukaan agregat lebih banyak dari pada total luas permukaan agregat maksimum yang besar. Perkiraan kebutuhan air ditunjukan pada Tabel 3.

Tabel 3. Perkiraan Kadar Air Bebas $\left[\mathrm{kg} / \mathrm{m}^{3}\right.$ ] yang Dibutuhkan untuk Beberapa Tingkat Kemudahan Pekerjaan Adukan untuk Kondisi Agregat SSD

\begin{tabular}{cccccc}
\hline \multirow{2}{*}{ Ukuran besar butir agregat maksimum } & \multirow{4}{*}{ Jenis Agregat } & \multicolumn{4}{c}{ Slum $[\mathbf{m m}]$} \\
\cline { 3 - 5 } & & $\mathbf{0 - 1 0}$ & $\mathbf{1 0 - 3 0}$ & $\mathbf{3 0 - 6 0}$ & $\mathbf{6 0 - 1 8 0}$ \\
\hline \multirow{2}{*}{10} & Batu tak dipecahkan & 150 & 180 & 205 & 225 \\
& Batu pecah & 180 & 205 & 230 & 250 \\
\multirow{2}{*}{20} & Batu tak dipecahkan & 135 & 160 & 180 & 195 \\
& Batu pecah & 170 & 190 & 210 & 225 \\
\multirow{2}{*}{40} & Batu tak dipecahkan & 115 & 140 & 160 & 175 \\
& Batu pecah & 155 & 175 & 190 & 205 \\
\hline
\end{tabular}

(Sumber: Badan Standardisasi Nasional, 2000)

\subsection{Pengaruh Gradasi Agregat terhadap Kelecakan Campuran Beton}

Pengaruh gradasi terhadap kelecakan campuran beton telah diteliti oleh Newman dan Teychenne (1954) yang hasilnya diperlihatkan pada Tabel 4 dan Tabel 5.

Tabel 4. Pengaruh Gradasi terhadap Kelecakan Campuran Beton

\begin{tabular}{|c|c|c|c|c|}
\hline Uraian & $\begin{array}{l}\text { Campuran } \\
\text { Beton } 1\end{array}$ & $\begin{array}{l}\text { Campuran } \\
\text { Beton } 2\end{array}$ & $\begin{array}{l}\text { Campuran } \\
\text { Beton } 3\end{array}$ & $\begin{array}{l}\text { Campuran } \\
\text { Beton } 4\end{array}$ \\
\hline $\begin{array}{l}\text { Permukaan spesifik agregat } \\
\text { secara keseluruhan }\left[\mathrm{m}^{2} / \mathrm{kg}\right]\end{array}$ & 2,55 & 2,55 & 2,55 & 2,55 \\
\hline $\begin{array}{l}\text { Persentasi pasir } \\
\text { Proporsi berdasarkan volume } \\
\text { Air-semen dalam berat }\end{array}$ & $\begin{array}{l}46 \\
1 ; 2,5 ; 3,5 \\
0,6\end{array}$ & $\begin{array}{c}36 \\
1 ; 2 ; 4 \\
0,6\end{array}$ & $\begin{array}{c}29 \\
1 ; 1,5 ; 4,5 \\
0,6\end{array}$ & $\begin{array}{c}24 \\
1 ; 1,25 ; 4,75 \\
0,6\end{array}$ \\
\hline $\begin{array}{c}\text { Faktor kepadatan } \\
\text { [compacting factor }]\end{array}$ & 0,92 & 0,93 & 0,93 & 0,93 \\
\hline $\begin{array}{l}\text { Kuat tekan umur } 28 \text { hari } \\
{[\mathrm{MPa}]}\end{array}$ & 27,1 & 28,1 & 29,2 & 29 \\
\hline
\end{tabular}

Tabel 5. Pengaruh Gradasi terhadap Kelecakan Campuran Beton

\begin{tabular}{ccccc} 
Uraian & $\begin{array}{c}\text { Campuran } \\
\text { Beton 1 }\end{array}$ & $\begin{array}{c}\text { Campuran } \\
\text { Beton 2 }\end{array}$ & $\begin{array}{c}\text { Campuran } \\
\text { Beton 3 }\end{array}$ & $\begin{array}{c}\text { Campuran } \\
\text { Beton 4 }\end{array}$ \\
\hline Permukaan spesifik agregat & 2,08 & 2,55 & 3,04 & 3,55 \\
secara keseluruhan [m²/kg] & 36 & 36 & 36 & 36 \\
$\quad$ Persentasi pasir & $1 ; 2 ; 4$ & $1 ; 2 ; 4$ & $1 ; 2 ; 4$ & $1 ; 2 ; 4$ \\
$\begin{array}{c}\text { Proporsi berdasarkan volume } \\
\text { Air-semen dalam berat }\end{array}$ & 0,58 & 0,60 & 0,63 & 0,66 \\
$\quad \begin{array}{c}\text { Faktor kepadatan } \\
\text { [compacting factor] }\end{array}$ & 0,92 & 0,95 & 0,95 & 0,96 \\
Kuat tekan umur 28 hari & 31,6 & 28,9 & 24,8 & 23,2 \\
$\quad$ [MPa] & & & &
\end{tabular}

Hasil dari penelitian Newman dan Teychenne (1954) pada Tabel 4 dan Tabel 5 menunjukkan bahwa gradasi agregat berpengaruh terhadap tingkat kelecakan. Jika Permukaan spesifik agregat secara keseluruhan memiliki nilai yang sama, maka tingkat kelecakan campuran beton yang dihasilkan tidak akan jauh berbeda. Jika permukaan agregat secara keseluruhan memiliki nilai yang berbeda, maka tingkat kelecakannya akan berbedabeda. Hal yang sama mengenai pengaruh gradasi terhadap kelecakan campuran beton diteliti juga oleh Saelan dan Arifin (2002) dimana gradasi agregat dinyatakan dalam modulus kehalusan yang ditunjukan pada Tabel 6. 
Tabel 6. Komposisi Campuran Beton dengan Nilai Modulus Kehalusan yang Sama

\begin{tabular}{cccccc}
\hline \multirow{2}{*}{ Ukuran saringan [mm] } & Gradasi & \multicolumn{5}{c}{ Gradasi actual [\%] } \\
\cline { 3 - 6 } & acuan & MF-I & MF-II & MF-III & MF-IV \\
\hline $20-10$ & 56,5 & 58 & 61,5 & 62 & 65 \\
$10-5$ & 5,5 & - & - & - & - \\
$5-2,5$ & 5 & 9 & - & - & - \\
$2,5-1,2$ & 7 & 8 & 10 & - & - \\
$1,2-0,6$ & 6 & 7 & 9 & 18 & - \\
$0,6-0,3$ & 6,5 & 6,5 & 7,5 & 12 & 29 \\
$0,3-1,15$ & 6,5 & 6 & 6,5 & 7 & 6 \\
$<0,15$ & 7 & 5,5 & 5,5 & 1 & - \\
Modulus kehalusan & 5,19 & 5,19 & 5,19 & 5,19 & 5,19 \\
Air-semen & 2,00 & 2,00 & 2,00 & 2,00 & 2,00 \\
Slump rencana & 40 & 40 & 40 & 40 & 40 \\
Slump actual & 35 & 35 & 35 & 40 & 40 \\
Kuat tekan aktual [MPa], 33 hari & 35,35 & 35,35 & 40,127 & 36,306 & 36,943 \\
\hline
\end{tabular}

Tabel 6 menunjukan bahwa komposisi dari campuran beton yang bergradasi diskontinu atau gradasi tidak menerus memiliki nilai modulus kehalusan dan nilai air-semen sama, dan tingkat kelecakan yang hampir sama. Hal ini dapat disimpulkan bahwa agregat yang memiliki nilai modulus kehalusan dan nilai air-semen yang sama tidak akan mempengaruhi tingkat kelecakan dan tidak dipengaruhi oleh gradasi agregat pada campuran beton.

\subsection{Kebutuhan Air Dalam Campuran Beton pada Cara SNI}

Perkiraan kadar air bebas kondisi SSD pada Tabel 8 telah dimodifikasi oleh Awali, I. F. (2018) untuk kondisi agregat kering udara (air dry), yang ditunjukan pada Tabel 7.

Tabel 7. Perkiraan Kadar Air $\left[\mathrm{kg} / \mathrm{m}^{3}\right.$ ] yang Digunakan untuk Beberapa Tingkat Kelecakan Campuran Beton pada Kondisi Agregat Kering Udara

\begin{tabular}{cccccc}
\hline Ukuran Besar Butir & Jenis Agregat & \multicolumn{4}{c}{ Slump $[\mathbf{m m}]$} \\
\cline { 2 - 6 } Agregat Maksimum & $\mathbf{0 - 1 0}$ & $\mathbf{1 0 - 3 0}$ & $\mathbf{3 0 - 6 0}$ & $\mathbf{6 0 - 1 8 0}$ \\
\hline 10 & $\begin{array}{c}\text { Batu tak dipecahkan } \\
\text { Batu pecah } \\
20\end{array}$ & 205 & 216 & 229 & 255 \\
Batu tak dipecahkan & 188 & 198 & 210 & 236 \\
40 & $\begin{array}{c}\text { Batu pecah } \\
\text { Batu tak dipecahkan } \\
\text { Batu Pecah }\end{array}$ & 177 & 186 & 198 & 222 \\
\hline
\end{tabular}

Kebutuhan air pada campuran beton untuk mencapai suatu kelecakan dipengaruhi oleh ukuran besar butir agregat maksimum, dan jenis agregat. Semakin besar agregat maksimum, maka semakin sedikit kebutuhan air yang diperlukan untuk mencapai suatu kelecakan campuran beton. Jika agregat maksimum lebih kecil, maka kebutuhan air untuk membasahi total luas permukaan agregat akan semakin banyak dari pada total luas permukaan agregat maksimum yang lebih besar. Ukuran maksimum agregat yang terdapat pada perkiraan jumlah air yang dibutuhkan untuk mencapai kelecakan pada cara SNI tidak menunjukan gradasi agregat kasar secara jelas. Berdasarkan definisi agregat kasar yaitu agregat yang berukuran lebih dari 4,75 mm, maka untuk ukuran agregat maksimum $10 \mathrm{~mm}$, $20 \mathrm{~mm}$, dan $40 \mathrm{~mm}$ dianggap sebagai agregat bergradasi seragam. Anggapan ini didasarkan pada ukuran maksimum agregat $10 \mathrm{~mm}$ yang merupakan agregat yang berukuran $4,75-10$ $\mathrm{mm}$, yang merupakan gradasi seragam. Jika pada ukuran maksimum $20 \mathrm{~mm}$ dan $40 \mathrm{~mm}$ merupakan gradasi menerus, maka kebutuhan air dapat diperhitungkan berbanding lurus dengan persentase dari masing-masing ukuran. Dengan demikian maka diduga perkiraan 
kadar air yang dibutuhkan untuk campuran beton cara SNI dipengaruhi oleh gradasi agregat kasar. Dengan demikian dapat diajukan perkiraan jumlah air total yang digunakan untuk mencapai suatu nilai s/ump rencana, yang dirumuskan pada Persamaan 1 sebagai berikut:

Jumlah air total $=\Sigma \%$ ukuran agregat kasar $*$ jumlah air tiap ukuran agregat kasar

\section{METODOLOGI PENELITIAN}

\subsection{Prosedur Penelitian}

Prosedur penelitian mengenai pengaruh gradasi agregat terhadap kebutuhan air untuk mencapai kelecakan campuran beton pada cara SNI dilakukan dengan tahapan-tahapan yang ditunjukan pada Gambar 1.

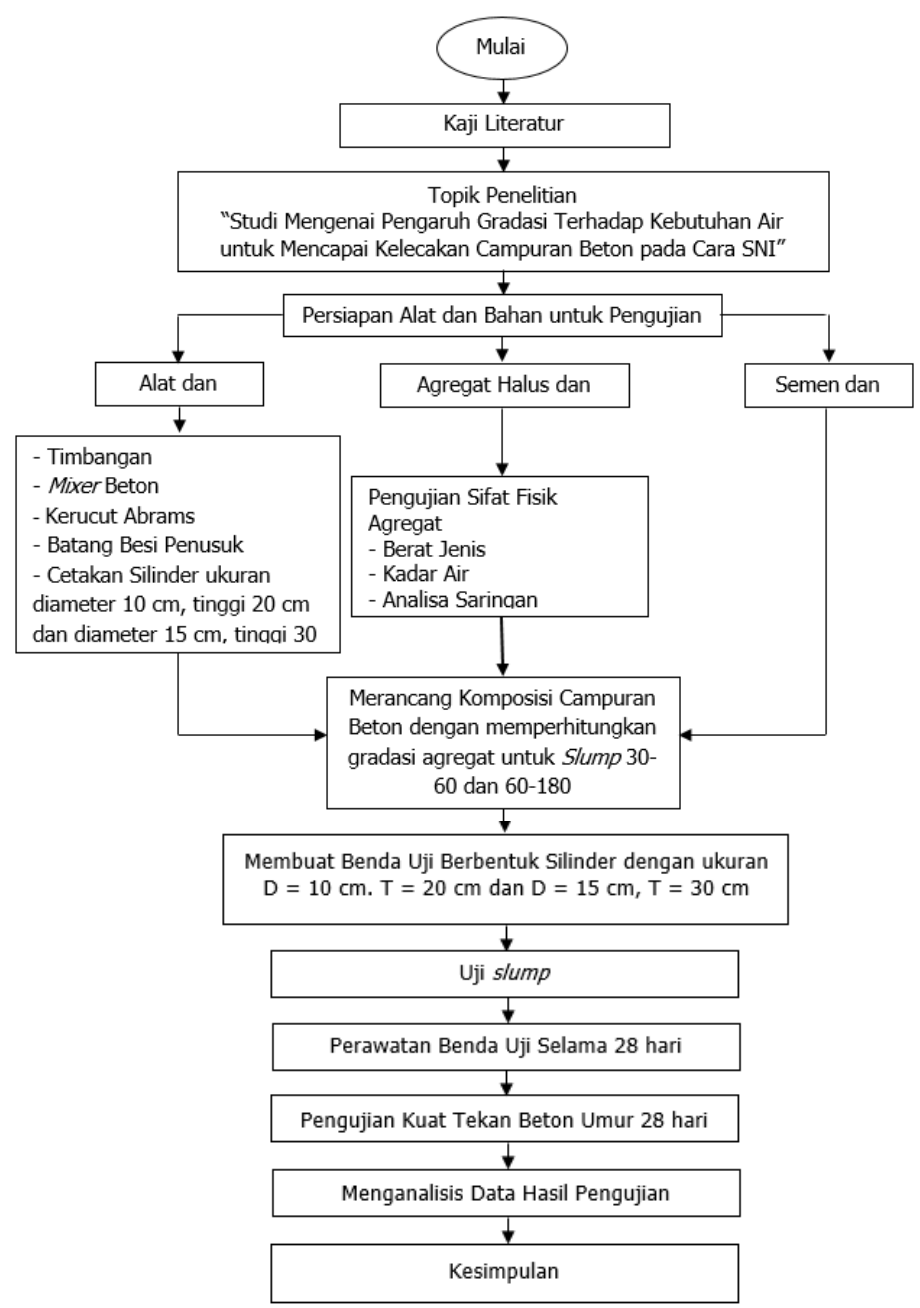

Gambar 1. Bagan alir metode penelitian

\subsection{Data Penelitian}

Data penelitian yang digunakan yaitu data sekunder dan data primer. Data primer yang digunakan adalah sebagai berikut:

1. Data perkiraan kadar air $\left[\mathrm{kg} / \mathrm{m}^{3}\right]$ yang digunakan untuk beberapa tingkat kelecakan campuran beton pada kondisi kering udara untuk beberapa variasi gradasi agregat kasar, yang dimodifikasi berdasarkan data sekunder hasil penelitian dari Awali, I. F. (2018) pada Tabel 8.

2. Data komposisi bahan campuran beton yang ditunjukan pada Tabel 8, Tabel 9, Tabel 
10, dan Tabel 11.

Tabel 8. Komposisi Kadar Air [ $\mathrm{kg} / \mathrm{m}^{3}$ ] yang Digunakan untuk Beberapa Tingkat Kelecakan Campuran Beton pada Kondisi Agregat Kering Udara yang Telah Dimodifikasi

\begin{tabular}{cccccc}
\hline $\begin{array}{c}\text { Ukuran Besar } \\
\text { Butir Agregat } \\
\text { Maksimum }\end{array}$ & Jenis Agregat & $\mathbf{0 - 1 0}$ & $\mathbf{1 0 - 3 0}$ & $\mathbf{3 0 - 6 0}$ & $\mathbf{6 0 - 1 8 0}$ \\
\cline { 3 - 6 } & Batu tak dipecahkan & 205 & 216 & 229 & 255 \\
\hline 10 & $\begin{array}{c}\text { Batu pecah } \\
\text { Batu tak dipecahkan } \\
\text { Batu pecah }\end{array}$ & 188 & 198 & 210 & 236 \\
40 & $\begin{array}{c}\text { Batu tak dipecahkan } \\
\text { Batu pecah }\end{array}$ & 177 & 186 & 198 & 222 \\
\hline
\end{tabular}

Tabel 9. Komposisi Campuran Beton Ukuran Agregat Maksimum 10 mm

\begin{tabular}{|c|c|c|c|c|c|c|c|}
\hline \multirow{2}{*}{\multicolumn{3}{|c|}{ Komposisi Gradasi [\%] }} & \multirow{3}{*}{ Bahan } & \multicolumn{4}{|c|}{ Slump $[\mathrm{mm}]$} \\
\hline & & & & \multicolumn{2}{|c|}{ Untuk $1 \mathbf{~ m}^{3}$} & \multicolumn{2}{|c|}{ Untuk 4 silinder } \\
\hline 10 & 20 & 40 & & $30-60$ & $60-180$ & $30-60$ & $60-180$ \\
\hline \multirow{4}{*}{100} & \multirow{4}{*}{-} & \multirow{4}{*}{ - } & Air $[\mathrm{kg}]$ & 229 & 255 & 1,582 & 1,761 \\
\hline & & & Semen $[\mathrm{kg}]$ & 400 & 400 & 2,764 & 2,764 \\
\hline & & & Pasir [kg] & 957,58 & 957,58 & 6,616 & 6,616 \\
\hline & & & Batu Pecah [kg] & 637,26 & 647,58 & 4,404 & 4,472 \\
\hline
\end{tabular}

Tabel 10. Komposisi Campuran Beton Ukuran Agregat Maksimum 20 mm

\begin{tabular}{|c|c|c|c|c|c|c|c|}
\hline \multirow{2}{*}{\multicolumn{3}{|c|}{ Komposisi Gradasi [\%] }} & \multirow{3}{*}{ Bahan } & \multicolumn{4}{|c|}{ Slump $[\mathrm{mm}]$} \\
\hline & & & & \multicolumn{2}{|c|}{ Untuk $1 \mathrm{~m}^{3}$} & \multicolumn{2}{|c|}{ Untuk 4 silinder } \\
\hline 10 & 20 & 40 & & $30-60$ & $60-180$ & $30-60$ & $60-180$ \\
\hline \multirow{4}{*}{-} & \multirow{4}{*}{100} & \multirow[t]{4}{*}{ 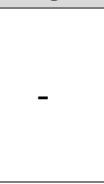 } & Air [kg] & 210 & 236 & 1,451 & 1,541 \\
\hline & & & Semen $[\mathrm{kg}]$ & 400 & 400 & 2,764 & 2,764 \\
\hline & & & Pasir $[\mathrm{kg}]$ & 957,58 & 957,58 & 6,616 & 6,616 \\
\hline & & & Batu Pecah [kg] & 702,24 & 739,2 & 4,851 & 5,106 \\
\hline \multirow{4}{*}{25} & \multirow{4}{*}{75} & \multirow{4}{*}{ - } & Air $[\mathrm{kg}]$ & 214,75 & 240,75 & 1,483 & 1,663 \\
\hline & & & Semen $[\mathrm{kg}]$ & 400 & 400 & 2,764 & 2,764 \\
\hline & & & Pasir $[\mathrm{kg}]$ & 957,58 & 957,58 & 6,616 & 6,616 \\
\hline & & & Batu Pecah [kg] & 685,12 & 616,875 & 4,733 & 4,261 \\
\hline \multirow{4}{*}{50} & \multirow{4}{*}{50} & \multirow{4}{*}{ - } & Air $[\mathrm{kg}]$ & 219,5 & 245,5 & 1,516 & 1,696 \\
\hline & & & Semen $[\mathrm{kg}]$ & 400 & 400 & 2,764 & 2,764 \\
\hline & & & Pasir $[\mathrm{kg}]$ & 957,58 & 957,58 & 6,616 & 6,616 \\
\hline & & & Batu Pecah [kg] & 670,77 & 602,91 & 4,634 & 4,165 \\
\hline \multirow{4}{*}{75} & \multirow{4}{*}{25} & \multirow{4}{*}{ - } & Air $[\mathrm{kg}]$ & 224,25 & 250,25 & 1,549 & 1,729 \\
\hline & & & Semen $[\mathrm{kg}]$ & 400 & 400 & 2,764 & 2,764 \\
\hline & & & Pasir [kg] & 957,58 & 957,58 & 6,616 & 6,616 \\
\hline & & & Batu Pecah [kg] & 653,94 & 586,47 & 4,517 & 4,051 \\
\hline
\end{tabular}

Tabel 11. Komposisi Campuran Beton Ukuran Agregat Maksimum 40 mm

\begin{tabular}{|c|c|c|c|c|c|c|c|}
\hline \multirow{2}{*}{\multicolumn{3}{|c|}{ Komposisi Gradasi [\%] }} & \multirow{3}{*}{ Bahan } & \multicolumn{4}{|c|}{ Slump [mm] } \\
\hline & & & & \multicolumn{2}{|c|}{ Untuk $1 \mathbf{~ m}^{3}$} & \multicolumn{2}{|c|}{ Untuk 4 silinder } \\
\hline 10 & 20 & 40 & & $30-60$ & $60-180$ & $30-60$ & $60-180$ \\
\hline & \multirow{4}{*}{-} & \multirow{4}{*}{100} & Air [kg] & 198 & 222 & 3,463 & 3,883 \\
\hline & & & Semen $[\mathrm{kg}]$ & 400 & 400 & 6,996 & 6,996 \\
\hline & & & Pasir [kg] & 957,58 & 957,58 & 16,748 & 16,748 \\
\hline & & & Batu Pecah $[\mathrm{kg}]$ & 750,6 & 664,2 & 13,128 & 11,617 \\
\hline
\end{tabular}


Tabel 11. Komposisi Campuran Beton Ukuran Agregat Maksimum 40 mm lanjutan

\begin{tabular}{|c|c|c|c|c|c|c|c|}
\hline \multirow{2}{*}{\multicolumn{3}{|c|}{ Komposisi Gradasi [\%] }} & \multirow{3}{*}{ Bahan } & \multicolumn{4}{|c|}{ Slump [mm] } \\
\hline & & & & \multicolumn{2}{|c|}{ Untuk $1 \mathbf{~ m}^{3}$} & \multicolumn{2}{|c|}{ Untuk 4 silinder } \\
\hline 10 & 20 & 40 & & $30-60$ & $60-180$ & $30-60$ & $60-180$ \\
\hline \multirow{4}{*}{25} & \multirow{4}{*}{-} & \multirow{4}{*}{75} & Air [kg] & 205,75 & 230,25 & 3,599 & 4,027 \\
\hline & & & Semen $[\mathrm{kg}]$ & 400 & 400 & 6,996 & 6,996 \\
\hline & & & Pasir $[\mathrm{kg}]$ & 957,58 & 957,58 & 16,748 & 16,748 \\
\hline & & & Batu Pecah [kg] & 720,9 & 667,89 & 12,609 & 11,488 \\
\hline \multirow{4}{*}{50} & \multirow{4}{*}{-} & \multirow{4}{*}{50} & Air $[\mathrm{kg}]$ & 213,5 & 238,5 & 3,734 & 4,171 \\
\hline & & & Semen $[\mathrm{kg}]$ & 400 & 400 & 6,996 & 6,996 \\
\hline & & & Pasir [kg] & 957,58 & 957,58 & 16,748 & 16,748 \\
\hline & & & Batu Pecah [kg] & 694,32 & 628,32 & 12,144 & 10,989 \\
\hline \multirow{4}{*}{75} & \multirow{4}{*}{ - } & \multirow{4}{*}{25} & Air $[\mathrm{kg}]$ & 221,25 & 246,75 & 3,87 & 4,316 \\
\hline & & & Semen $[\mathrm{kg}]$ & 400 & 400 & 6,996 & 6,996 \\
\hline & & & Pasir $[\mathrm{kg}]$ & 957,58 & 957,58 & 16,748 & 16,748 \\
\hline & & & Batu Pecah [kg] & 665,55 & 597,69 & 11,466 & 10,139 \\
\hline \multirow{4}{*}{ - } & \multirow{4}{*}{25} & \multirow{4}{*}{75} & Air $[\mathrm{kg}]$ & 201 & 225.5 & 3,515 & 3,944 \\
\hline & & & Semen $[\mathrm{kg}]$ & 400 & 400 & 6,996 & 6,996 \\
\hline & & & Pasir [kg] & 957,58 & 957,58 & 16,748 & 16,748 \\
\hline & & & Batu Pecah [kg] & 665,88 & 673,935 & 11,646 & 11,787 \\
\hline \multirow{4}{*}{ - } & \multirow{4}{*}{50} & \multirow{4}{*}{50} & Air $[\mathrm{kg}]$ & 204 & 229 & 3,568 & 4,005 \\
\hline & & & Semen $[\mathrm{kg}]$ & 400 & 400 & 6,996 & 6,996 \\
\hline & & & Pasir [kg] & 957,58 & 957,58 & 16,748 & 16,748 \\
\hline & & & Batu Pecah [kg] & 726,24 & 659,49 & 12,702 & 11,534 \\
\hline \multirow{4}{*}{ - } & \multirow{4}{*}{72} & \multirow{4}{*}{25} & Air $[\mathrm{kg}]$ & 207 & 232,5 & 3,62 & 4,066 \\
\hline & & & Semen $[\mathrm{kg}]$ & 400 & 400 & 6,996 & 6,996 \\
\hline & & & Pasir [kg] & 957,58 & 957,58 & 16,748 & 16,748 \\
\hline & & & Batu Pecah [kg] & 714,195 & 647,82 & 12,491 & 11,33 \\
\hline \multirow{4}{*}{25} & \multirow{4}{*}{25} & \multirow{4}{*}{50} & Air $[\mathrm{kg}]$ & 208,75 & 233,75 & 3,651 & 4,088 \\
\hline & & & Semen $[\mathrm{kg}]$ & 400 & 400 & 6,996 & 6,996 \\
\hline & & & Pasir [kg] & 957,58 & 957,58 & 16,748 & 16,748 \\
\hline & & & Batu Pecah [kg] & 708,885 & 642,51 & 12,398 & 11,234 \\
\hline & & & Air $[\mathrm{kg}]$ & 211,75 & 237,25 & 3,704 & 4,15 \\
\hline 25 & 50 & 50 & Semen $[\mathrm{kg}]$ & 400 & 400 & 6,996 & 6,996 \\
\hline 25 & 50 & 50 & Pasir [kg] & 957,58 & 957,58 & 16,748 & 16,748 \\
\hline & & & Batu Pecah [kg] & 696,96 & 630,96 & 12,19 & 11,035 \\
\hline & & & Air $[\mathrm{kg}]$ & 216,5 & 242 & 3,787 & 4,233 \\
\hline & & & Semen $[\mathrm{kg}]$ & 400 & 400 & 6,996 & 6,996 \\
\hline 50 & 25 & 25 & Pasir $[\mathrm{kg}]$ & 957,58 & 957,58 & 16,748 & 16,748 \\
\hline & & & Batu Pecah [kg] & 682,5 & 614,25 & 11,937 & 10,743 \\
\hline
\end{tabular}

\section{HASIL PENELITIAN DAN PEMBAHASAN}

\subsection{Hasil Penelitian}

Nilai s/ump yang terjadi menggunakan kebutuhan air yang dihitung dengan cara perbandingan lurus ini masih berada pada rentang nilai slump yang direncanakan, yang hasilnya dapat dilihat pada Tabel 12 dan Tabel 13. 
Tabel 12. Hasil Kuat Tekan Beton untuk Nilai Slump Rencana 30-60 mm

\begin{tabular}{|c|c|c|c|c|c|c|c|c|c|c|}
\hline \multirow{2}{*}{$\begin{array}{c}\text { Ukuran } \\
\text { Maksimum } \\
\text { Butiran } \\
\text { [mm] }\end{array}$} & \multirow{2}{*}{$\begin{array}{c}\text { No } \\
\text { Benda } \\
\text { Uji }\end{array}$} & \multicolumn{3}{|c|}{ Gradasi [\%] } & \multirow{2}{*}{$\begin{array}{c}\text { Jumlah } \\
\text { Air } \\
{\left[\mathbf{k g} / \mathrm{m}^{3}\right]}\end{array}$} & \multirow{2}{*}{$\begin{array}{l}\text { Slump } \\
30-60 \\
\text { [mm] } \\
\text { Aktual }\end{array}$} & \multicolumn{2}{|c|}{$\begin{array}{c}\text { Kuat Tekan Rata-rata } \\
14 \text { hari [MPa] }\end{array}$} & \multicolumn{2}{|c|}{$\begin{array}{c}\text { Berat Rata-rata } \\
\text { [kg] }\end{array}$} \\
\hline & & 10 & 20 & 40 & & & Aktual & Prediksi & Aktual & Teoritis \\
\hline \multirow[t]{3}{*}{10} & 1 & 100 & - & - & 229 & 35 & 17,45 & 26,36 & 3,494 & 3,491 \\
\hline & 3 & - & 100 & - & 210 & 35 & 29,24 & 29,71 & 3,645 & 3,563 \\
\hline & 5 & & & & 214,75 & 50 & 23,85 & 28,82 & 3,559 & 3,544 \\
\hline \multirow{8}{*}{20} & $3 A$ & 25 & 75 & - & 210 & 35 & 23,74 & 29,71 & 3,564 & 3,536 \\
\hline & 7 & & & & 219,5 & 40 & 25,38 & 27,97 & 3,628 & 3,529 \\
\hline & $3 B$ & 50 & 50 & - & 210 & 15 & 26,19 & 29,71 & 3,590 & 3,514 \\
\hline & 9 & 75 & 25 & - & 224,25 & 30 & 21,95 & 27,15 & 3,528 & 3,510 \\
\hline & 11 & - & - & 100 & 198 & 15 & 27,47 & 32,15 & 12,174 & 12,222 \\
\hline & 13 & 25 & - & 75 & 205,75 & 40 & 21,01 & 30,58 & 12,060 & 12,106 \\
\hline & 15 & 50 & - & 50 & 213,5 & 50 & 23,32 & 29,05 & 12,037 & 12,006 \\
\hline & 17 & 75 & - & 25 & 221,25 & 60 & 13,16 & 27,66 & 11,927 & 11,895 \\
\hline \multirow{6}{*}{40} & 19 & - & 25 & 75 & 201 & 45 & 17,66 & 31,51 & 12,100 & 11,789 \\
\hline & 21 & - & 50 & 50 & 204 & 50 & 17,94 & 30,89 & 12,033 & 12,125 \\
\hline & 23 & - & 75 & 25 & 207 & 45 & 23,64 & 30,29 & 12,267 & 12,077 \\
\hline & 25 & 25 & 25 & 50 & 208,75 & 40 & 18,25 & 29,95 & 12,167 & 12,058 \\
\hline & 27 & 25 & 50 & 25 & 211,75 & 45 & 24,38 & 29,38 & 12,200 & 12,011 \\
\hline & 29 & 50 & 25 & 25 & 216,5 & 50 & 25,79 & 28,50 & 12,233 & 11,960 \\
\hline
\end{tabular}

Tabel 13. Hasil Kuat Tekan Beton untuk Nilai Slump Rencana 60-180 mm

\begin{tabular}{|c|c|c|c|c|c|c|c|c|c|c|}
\hline \multirow{2}{*}{$\begin{array}{c}\text { Ukuran } \\
\text { Maksimum } \\
\text { Butiran } \\
\text { [mm] }\end{array}$} & \multirow{2}{*}{$\begin{array}{c}\text { No } \\
\text { Benda } \\
\text { Uji }\end{array}$} & \multicolumn{3}{|c|}{ Gradasi [\%] } & \multirow{2}{*}{$\begin{array}{c}\text { Jumlah } \\
\text { Air } \\
{\left[\mathbf{k g} / \mathbf{m}^{3}\right]}\end{array}$} & \multirow{2}{*}{$\begin{array}{c}\text { Slump } \\
\text { Aktual } \\
\text { [mm] } \\
\text { Aktual }\end{array}$} & \multicolumn{2}{|c|}{$\begin{array}{c}\text { Kuat Tekan Rata-rata } \\
14 \text { hari [MPa] }\end{array}$} & \multicolumn{2}{|c|}{$\begin{array}{c}\text { Berat Rata-rata } \\
\text { [kg] }\end{array}$} \\
\hline & & 10 & 20 & 40 & & & Aktual & Prediksi & Aktual & Teoritis \\
\hline \multirow[t]{3}{*}{10} & 2 & 100 & - & - & 255 & 135 & 11,96 & 22,60 & 3,441 & 3,548 \\
\hline & 4 & - & 100 & - & 236 & 85 & 23,54 & 25,27 & 3,589 & 3,662 \\
\hline & 6 & & & & 240,75 & 150 & 19,38 & 24,56 & 3,526 & 3,478 \\
\hline \multirow{8}{*}{20} & $4 \mathrm{~A}$ & 25 & /5 & - & 236 & 75 & 21,97 & 25,27 & 3,563 & 3,429 \\
\hline & 8 & & & & 245,5 & 140 & 19,63 & 23,88 & 3,463 & 3,463 \\
\hline & $4 B$ & 50 & 50 & - & 236 & 25 & 22,66 & 25,27 & 3,597 & 3,448 \\
\hline & 10 & 75 & 25 & - & 250,25 & 100 & 17,25 & 23,23 & 3,435 & 3,445 \\
\hline & 12 & - & - & 100 & 222 & 85 & 19,74 & 27,53 & 11,956 & 11,892 \\
\hline & 14 & 25 & - & 75 & 230,25 & 100 & 19,24 & 26,17 & 11,971 & 11,955 \\
\hline & 16 & 50 & - & 50 & 238,5 & 135 & 18,19 & 24,89 & 11,682 & 11,789 \\
\hline & 18 & 75 & - & 25 & 246,75 & 100 & 16,02 & 23,71 & 11,900 & 11,671 \\
\hline \multirow{6}{*}{40} & 20 & - & 25 & 75 & 225,5 & 100 & 16,77 & 26,94 & 11,900 & 11,962 \\
\hline & 22 & - & 50 & 50 & 229 & 100 & 20,66 & 26,37 & 12,133 & 11,904 \\
\hline & 24 & - & 75 & 25 & 232,5 & 100 & 18,62 & 25,81 & 12,133 & 11,861 \\
\hline & 26 & 25 & 25 & 50 & 233,75 & 105 & 20,70 & 25,62 & 12,100 & 11,839 \\
\hline & 28 & 25 & 50 & 25 & 237,25 & 120 & 22,42 & 25,08 & 12,133 & 11,767 \\
\hline & 30 & 50 & 25 & 25 & 242 & 90 & 22,89 & 24,38 & 12,000 & 11,733 \\
\hline
\end{tabular}

\subsection{Pembahasan}

Adapun hasil pembahasan dari penelitian yang dilakukan yaitu sebagai berikut:

1. Jumlah air yang dibutuhkan untuk menghasilkan nilai s/ump yang direncanakan dihitung berdasarkan dugaan bahwa jumlah air berbanding lurus dengan persentase ukuran butiran dalam gradasi agregat. Sebagai contoh pada s/ump rencana $30-60 \mathrm{~mm}$ untuk agregat kasar berukuran maksimum $20 \mathrm{~mm}$, yang terdiri dari $25 \%$ ukuran agregat 10 $\mathrm{mm}$ dan $75 \%$ ukuran agregat $20 \mathrm{~mm}$, kebutuhan airnya adalah $(25 \% * 229)+(75 \% *$ $210)=214,75 \mathrm{~kg} / \mathrm{m}^{3}$.

2. Nilai s/ump yang terjadi menggunakan kebutuhan air yang dihitung dengan cara perbandingan lurus ini masih berada pada rentang nilai slump yang direncanakan. Nilai slump terjadi $15 \mathrm{~mm}$, yang lebih kecil dari rentang yang direncanakan yaitu 30-60 mm terjadi disebabkan oleh sangat keringnya kondisi agregat.

3. Nilai s/ump yang kebutuhan air campurannya tidak dihitung berdasarkan perbandingan lurus maka nilai slump yang terjadi lebih rendah dan keluar dari rentang yang direncanakan jika kandungan ukuran maksimum agregat kasar adalah $\leq 50 \%$. Hal ini 
terjadi pada ukuran maksimum butiran $20 \mathrm{~mm}$, yang terdiri dari $50 \%$ ukuran agregat 10 $\mathrm{mm}$ dan $50 \%$ ukuran agregat $20 \mathrm{~mm}$ dengan menggunakan perkiraan kebutuhan air yang sama.

4. Jika kandungan agregat kasar yang lebih kecil dari ukuran maksimum $\leq 25 \%$ dari total agregat kasar, pemberian air tanpa memperhitungkan perbandingan lurus maka nilai slump yang terjadi masih dalam rentang yang direncanakan. Hal ini terjadi pada ukuran maksimum butiran $20 \mathrm{~mm}$, yang terdiri dari $25 \%$ ukuran agregat $10 \mathrm{~mm}$ dan $75 \%$ ukuran agregat $20 \mathrm{~mm}$ dengan menggunakan perkiraan kebutuhan air yang sama.

5. Dari hasil-hasil yang didapat maka jumlah air yang diperlukan untuk mencapai suatu nilai slump berbanding lurus dengan persentase jumlah air pada masing-masing ukuran butiran agregat kasar dalam agregat kasar total.

6. Ditinjau dari hasil uji tekan terdapat banyak hasil uji tekan yang lebih rendah, bahkan terdapat hasil uji tekan yang sangat berjauhan. Berdasarkan perbandingan berat benda uji aktual terhadap berat benda uji teoritis, diduga tidak didapatkan berkurangnya kuat tekan uji dari kuat tekan prediksi yang diakibatkan oleh berkurangnya kepadatan beton secara signifikan. Penelusuran berkurangnya kuat tekan uji dilakukan berdasarkan tingkat kemiringan benda uji disaat akan dilakukan pengujian uji tekan, dimana hal tersebut mengakibatkan penekanan di sebagian titik permukaan benda uji yang mengakibatkan nilai kuat tekan tidak optimal, dapat ditunjukan pada Gambar $\mathbf{2}$ dan Gambar 3. Sekalipun demikian masih terdapat benda uji yang hasil uji tekannya mendekati kuat tekan prediksi, yaitu pada benda uji 3, benda uji 4, benda uji 7, dan benda uji 30. Hal ini menandakan bahwa jumlah air yang dihitung dengan cara perbandingan lurus gradasi agregat kasar tidak hanya menghasilkan slump yang sesuai dengan rentang slump rencana, juga menghasilkan kuat tekan yang berdekatan dengan kuat tekan rencana (kuat tekan prediksi).

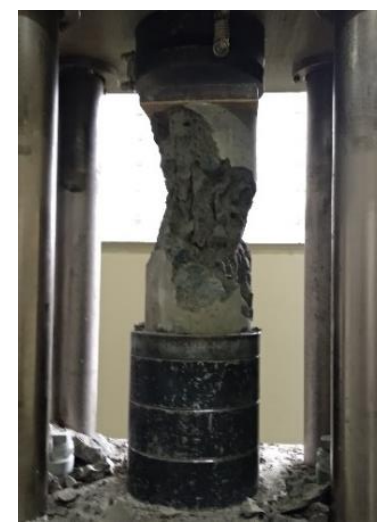

Gambar 2. Pola runtuh tekan uji yang lebih rendah dari hasil tekan prediksi

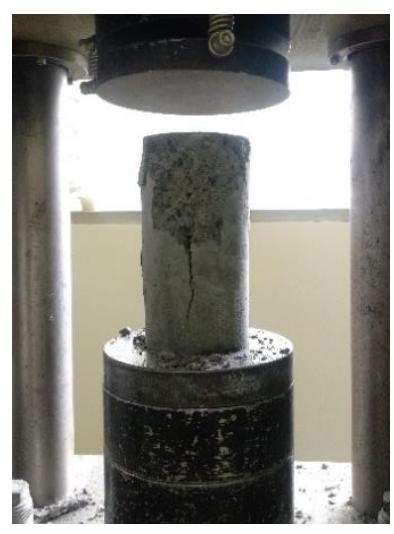

Gambar 3. Pola runtuh tekan uji mendekati hasil tekan prediksi

7. Berdasarkan hasil pengujian dan pembahasan hasil pengujian, perkiraan jumlah air dalam campuran beton untuk mencapai suatu kelacakan pada cara SNI dipengaruhi oleh gradasi agregat kasar dalam campuran beton. Perkiraan jumlah air dalam campuran beton berbanding lurus dengan jumlah air pada gradasi agregat kasar yang digunakan. Perkiraan jumlah air yang digunakan untuk mencapai suatu nilai slump rencana dapat dirumuskan: Jumlah air total $=\Sigma \%$ ukuran agregat kasar $*$ jumlah air tiap ukuran agregat kasar. 


\section{KESIMPULAN}

Dari hasil pengujian dan pembahasan yang dilakukan pada penelitian ini maka dapat disimpulkan:

1. Kebutuhan air dalam campuran beton pada cara SNI yang hanya ditentukan oleh ukuran maksimum agregat kasar masih ditentukan pula oleh keragaman gradasi agregat kasar tersebut.

2. Jumlah air yang diperlukan dalam campuran beton berbanding lurus dengan jumlah air pada gradasi agregat kasar yang digunakan, dan dapat dirumuskan menjadi: Jumlah air total $=\Sigma \%$ ukuran agregat kasar $*$ jumlah air tiap ukuran agregat kasar.

\section{SARAN}

Dalam perencanaan campuran beton pada cara SNI, sangat perlu diketahui gradasi agregat kasar yang digunakan, dinyatakan dalam modulus kehalusan agregat kasar, untuk mengetahui ketepatan jumlah air yang dibutuhkan untuk mencapai nilai slump yang direncanakan.

\section{DAFTAR RUJUKAN}

Awali, I. F. (2018). Modifikasi Jumlah Air dalam Campuran Beton Cara SNI untuk Kondisi Agregat Kering Udara. Tugas Akhir. Bandung: Juruan Teknik Sipil - Institut Teknologi Nasional - Bandung.

Badan Standardisasi Nasional. (2000). SNI 03-2834-2000 tentang Tata Cara Pembuatan Rencana Campuran Beton Normal. Jakarta: Badan Standardisasi Nasional.

Newman, J. \& Teychenne, D.C. (1954). Properties of Concrete. New Jersey: Pearson Prentice Hall.

Saelan, P. \& Arifin. (2002). Kaji Bandung Perencanaan Gradasi Bercelah dalam Campuran Beton dengan Menggunakan Cara Modulus Kehalusan dan Permukaan Spesifik. Tugas Akhir. Bandung: Jurusan Teknik Sipil Institut Teknologi Nasional - Bandung. 